\title{
Cohesion in TIME Magazine Article "How covid-19 will shape the class of 2020 for the rest of their live"
}

\author{
${ }^{1}$ Setyo Prasiyanto Cahyono, ${ }^{2}$ Valentina Widya Suryaningtyas, and ${ }^{3}$ Raden Arief \\ Nugroho \\ 1,2,3 Universitas Dian Nuswantoro, Semarang \\ (setyo.cahyono@dsn.dinus.ac.id)
}

Article History: Submitted August 14 ${ }^{\text {th }}, 2020$; Accepted August 28 ${ }^{\text {th }}, 2020$; Published August $30^{\text {th }}, 2020$

\begin{abstract}
This study is aimed at investigating the types of cohesive devices and their relationship which are found in an article of Time magazine entitled "how covid-19 will shape the class of 2020 for the rest of their live". In conducting this study, the researchers employ descriptive qualitative as the research design. Meanwhile, in collecting the data, the researcher applied a purposive sampling method by choosing an article in an on line Time magazine. Meanwhile, the text was analyzed using systemic functional linguistics (SFL) especially those contributing to the cohesion of the text, including grammatical and lexical cohesion. The result of this study reveals that the text is "hang-together" which is described by the successfully use of cohesive devices. These patterns indicate that the writer of the article introduces the capacity to create a text with cohesion not only at the clause level but also to create text with better unity, flow and connectedness of information of the whole text. Besides, the use of cohesion in the text can create a relationship between language elements. Furthermore, the text of the article uses some simple cohesive devices such as reference, conjunction, repetition, and synonym.
\end{abstract}

Keywords: cohesion, cohesive devices, language elements, magazine, SFL

Abstrak. Penelitian ini bertujuan untuk menyelidiki jenis perangkat kohesif dan keterkaitannya dalam artikel majalah Time berjudul "how covid-19 will shape the class of 2020 for the rest of their live". Dalam penelitian ini, peneliti menggunakan metode deskriptif kualitatif. Sedangkan dalam pengumpulan data, peneliti menggunakan sampel purposive dengan memilih artikel di majalah on line Time. Sedangkan teks dianalisis dengan menggunakan linguistik fungsional sistemik (LFS) terutama yang berkontribusi pada kohesi teks, termasuk kohesi gramatikal dan leksikal. Hasil penelitian ini menunjukkan bahwa teks yang dihasilkan oleh penulis "saling terpadu" yang digambarkan dengan berhasilnya penggunaan elemen perangkat kohesif. Pola-pola ini menunjukkan bahwa penulis artikel memunculkan kapasitas untuk membuat teks dengan kohesi tidak hanya pada tingkat klausa tetapi juga untuk membuat teks dengan kesatuan, aliran, dan keterhubungan informasi yang lebih baik dari keseluruhan teks. Selain itu penggunaan kohesi dalam teks dapat menciptakan hubungan antar elemen bahasa. Lebih lanjut lagi, teks tersebut menggunakan beberapa perangkat kohesif sederhana seperti referensi, konjungsi dan juga pengulangan, dan sinonim.

Kata kunci: kohesi, peranti kohesi, unsur bahasa, LSF, majalah, perangkat kohesif

\section{INTRODUCTION}

Discourse analysis is a rapidly developing and evolving field. Current research on discourse analysis has now flown from numerous academic disciplines that are very different from one to another (Schiffrin, Tannen and Hamilton, 2001). According to Renkema (1993: 1) discourse is the study which investigates the relationship of verbal communication in term 
of form and function. In relation to systemic functional linguistic (SFL), the term discourse interfaces with the analysis of grammar and analysis of social activity, somewhere between the work of grammarians on the other hand and social theorists on the other (Martin and Rose, 2003: 3)

Discourse can be from spoken, written, visual and audio form. However, his is different from a text where it is usually $\mathrm{n}$ term of written form of communication information, which is a non-interactive nature. Every text whether written or spoken is a discourse and it consists sentences. Meanwhile, Widdowson (1973) argues that the different between discourse and text lies in its properties that discourse is made up of utterances having the property of coherence whereas text is made up of sentences having the property of cohesion. In so doing, the text is more dealing with written form such as a text in a newspaper, magazine, or book.

A good text should have a good texture. Texture refers to the way in which resources such as patterns of cohesion create texts that are both cohesive and coherent (Bartlett and O'Grady, 2017: 134). Cocerning SFL, if a text is defined as a single semantic unit, cohesion is one of two properties of textuality; the other, coherence, can be defined simply as a text's being consistent in logical term (Clarke in Bartlett and O'Grady, 2017: 404)

Cohesion refers to the 'non-structural text-forming relations'(Halliday and Hasan, 1976: 7 \& Halliday and Matthiessen, 2014: 114). In other words, it relates to the 'semantic ties' within text whereby a tie is made when there is some dependent link between items that combine to create meaning. Furthermore, cohesion is mainly concerned with extended discourse rather than with individual sentence (Flowerdew, 2013). As cited in Fernandico, cohesion is also designed to deal with words and phrases that generate a pattern of relations between lexical elements and structures to build an integrated and logical text (Trebits, 2009). Moreover, Thompson (2014: 215) states that cohesion refers to the linguistics tools by which the speaker can signal the experiential and interpersonal coherence of the text, and is thus a textual phenomenon we can point to features of the text that serve a cohesive function. Briefly, Fontaine (2013: 169) points out that the concept of cohesion is semantic rather than structural in the sense that it functions around the clause rather than within it. Martin and (1992: 1) models cohesive devices systematically as a semantic phenomenon. Nevertheless, cohesion plays as an important linguistics resources in the expression of coherent meanings, in contrast, where a text is lack of cohesive devices then it will make the sentences incoherent. Additionally, this study is carried out to answer the question "what types of cohesive devices are found in the article of TIME magazine entitled "how covid-19 will shape the class of 2020 for the rest of their live".

In relation to the introduction of this study, cohesion which is discussed in this study is dealing with systemic functional linguistics theory developed by Halliday. Not only Halliday but also his followers have some similar point about SFL that it is a theory of language as a social semiotic system which simply means that language is a system or in other words that a language is organized systematically (Halliday, 1978). Additionally, he states that SFL is a theory of language centered around the notion of language function (Halliday, 1994). It indicates that the language itself becomes the center of communication. Arguably, Fontaine (2013: 5) views that SFL focuses on the function of language. It means that language plays an important role for the speakers to create meaning. The idea of here is that language is organized as a system of options. This system enables the speakers to create meaning by choosing relevant options (Halliday and Matthiessen, 2004: 23). The approaches of function to language seeks to reveal more than structural grammar, they try to tell us something about meaning. 
Meanings, as described in SFL, are segmented into three comprises ideational meaning, interpersonal meaning and textual meaning (Halliday, 2014). He argues that these three kinds of meanings are particularly relevant. As cited in Thompson (2014: 28) ideational meanings refer to the use of language to talk about our experience of the world including the worlds in our own minds, to describe events and states and the entities involved in them. In other words, it talks about what is going on in the world or what is happening with the situation the speakers talk at that time. Additionally, it also involves the process types and circumstances. Whilst, we also used language to interact with other people, to establish and maintain relations with them, to influence their behavior, to express our own viewpoint in things in the world, and to elicit or change theirs is called interpersonal meaning. It indicates about who is taking part in the conversation such as the participant, their societal roles, their status and their social distance of relationship. He also states that textual meaning comprises the organization of message in ways that indicate how they fit in with the other message around them and with the wider context in which we are talking or writing. It can be said what part of language is playing or types of interaction whether it is monologue or dialog, the medium used whether it is spoken or written mode, and also its rhetorical mode.

Textual Meaning, one out of three meanings, is mostly applicable approach to analyze a written text whereas its purpose is to determine the text coherency and unity. For writers, who aware of SFL particularly textual meaning, use it to organize their messages in order to produce a well written text in term of its texture. It means something like 'texthood' and it arises out of semantic configuration of two kinds namely register and cohesion Moore as cited in Bartlett and O'Grady (2017: 423). Besides, it is used as an interaction between the writers and their readers (Thompson, 1996: 117).

The function of textual meaning in a language is to construct the speakers and the writers messages in which it makes them fit smoothly into the unfolding language they produced for example in conversation, or news article. Otherwise, to organize any text to be coherent, speakers and writers need to keep their readers or listeners well informed about where they are and where they are going (Butt, 2000: 134). This can be realized through coherence and cohesion.

Cohesion plays an important role in giving good texture of a text because it makes a text coherent. Thompson (1996: 147) suggests cohesion is a crucial linguistic resource in the expression of coherent meanings; otherwise if the text is lack of cohesive devices then it does not lead to coherent text or in another word, it is incoherent. Halliday (and Hasan (1976) as cited in Martin (1992: 382-384) segmented cohesion into 2 main types of cohesion namely grammatical cohesion including reference, ellipsis, substitution, conjunction as well as lexical conjunction covering repetition, synonym, antonym and meronymy. Grammatical cohesion is the words that arranged into a compound of sentences produced by grammatical features. Thus, lexical cohesion is lexical components that produce a combination of sentences (Paltridge, 2000: 131-134). The relation of theory of this study can be summarized in the table below. 
Table 1 Function/rank matrix for lexicogrammatical system (Halliday: 1973:141)

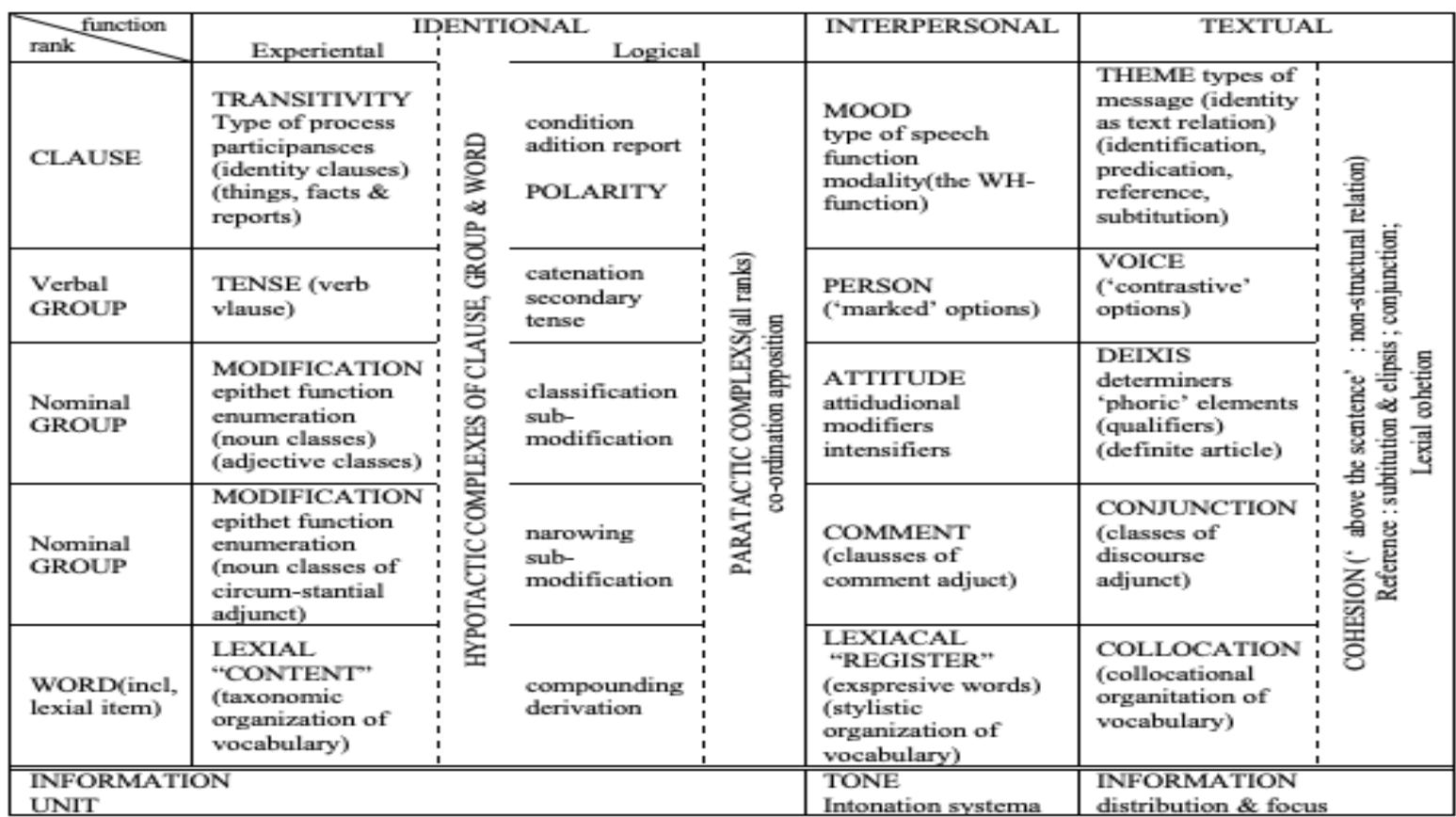

Source: Martin (1992: 18)

\section{METHOD}

This study analyzes cohesion found in the online article in TIME Magazine. For the research design, this study employed descriptive qualitative research method especially text analysis. In collecting the data, the researchers used a purposive sampling method and selected on line TIME magazine as the data source of this study. The data were retrieved from https://time.com/5839765/college-graduation-2020/ and were downloaded on 2 June 2020. Meanwhile, in order to analyze the links between texts, Halliday and Hassan's (1976) theory was applied as the approach to analyze the text. There were some steps in analyzing the data as described below.

First, one is tabulating the data. In this part of the data analysis the researchers made a table to classify the cohesion tool.

Second, the researchers described grammatical cohesion found in the data by classifying the clauses which contain the elements of grammatical cohesion including reference, substitution, ellipsis, and conjunction.

Third, after it had been classified into types of grammatical cohesion, then it was segmented into types of lexical cohesion comprises repetition, synonym, hyponym, antonym, and meronymy.

The last, the researchers give description and elaboration to each of types of cohesion in term of grammatical and lexical cohesion.

\section{FINDINGS AND DISCUSSION}

The findings of this study are discussed in relation to the question that was previously specified in the introduction. The summary of its findings can be seen in the table provided below. 
Table 2 Number of Cohesive Devices found in the Article in TIME Magazine

\begin{tabular}{|c|c|c|c|c|}
\hline No & Types of Cohesion & & Total Number & Percentage (\%) \\
\hline \multirow[t]{4}{*}{1} & \multirow{4}{*}{$\begin{array}{l}\text { Grammatical } \\
\text { Cohesion }\end{array}$} & Reference & 123 & $18,87 \%$ \\
\hline & & Ellipsis & 76 & $11,66 \%$ \\
\hline & & Substitution & 57 & $8,74 \%$ \\
\hline & & Conjunction & 113 & $17,33 \%$ \\
\hline \multirow[t]{4}{*}{2} & \multirow[t]{4}{*}{ Lexical Cohesion } & Repetition & 146 & $22,39 \%$ \\
\hline & & Synonym & 107 & $16,41 \%$ \\
\hline & & Antonym & 17 & $2,61 \%$ \\
\hline & & Hyponym & 13 & $1,99 \%$ \\
\hline Tota & No & & 652 & $100 \%$ \\
\hline
\end{tabular}

It can be seen in the table above that the highest number of grammatical cohesive devices found in the article is the reference. This is indicated by the use of personal reference which is commonly occurred in the article. Then, it is followed by conjunction in the second place. After that, substitution followed in the third place. The last is ellipsis which is rarely found in the data. Meanwhile, the highest number of lexical cohesive devices is repetition with 203.Then, it is followed by synonyms with 128 occurrences and the least number of lexical cohesive devices found is hyponym with 92 . Thus, the antonym is rarely found in the data. The example of these occurrences can be seen in the excerpts below

\section{Grammatical Cohesive Devices}

\section{Reference}

In this part of the analysis, we provide some examples of grammatical cohesive devices in particular reference. A brief explanation of this reference can be found in the following analysis and description below.

Excerpt 1

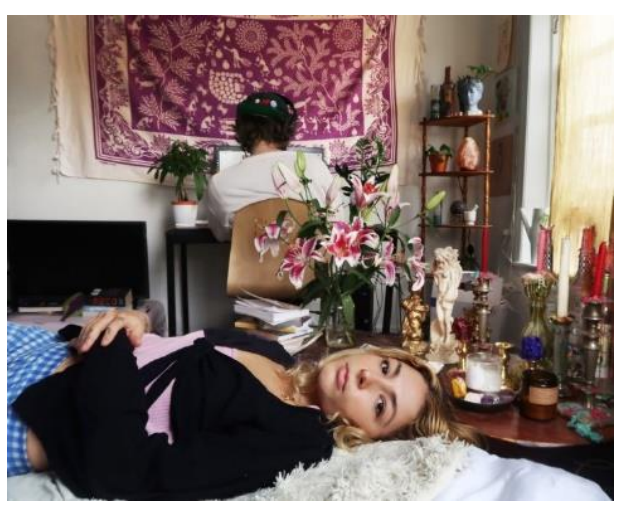

Elissa DeFranceschi, Drexel University Class of 2020, with her boyfriend in Philadelphia

Hannah Beier

How COVID-19 Will Shape the Class of 2020

For the Rest of Their Lives?

Hannah Beier 
MAY 21, 2020 6:57 AM EDT

They call it commencement because $\underline{i t}^{\prime}$ s supposed to be a new beginning.

It can be seen above that it contains some references which are indicated by the use of personal pronoun references such as they, her and it. Based on the example provided in the table above, it is found that the word her functions as an anaphoric reference. It describes the use of a word or phrase that refers to another word or phrase used earlier in a text. It can be seen that the object pronoun her refers to the name of Elissa DeFranceschi. Meanwhile, the subject pronoun They refers to both Elissa DeFranceschi and her boyfriend named Hannah Beiber.. Whereas, both pronouns it in the example above explain the phrase of the class of 2020. As a result, it can be said that these references plays a crucial roles in developing the idea of the main idea of an article because these references link the clauses into cohesive text.

Another reference example found in the data can be seen in the following table below.

\section{Excerpt 2}

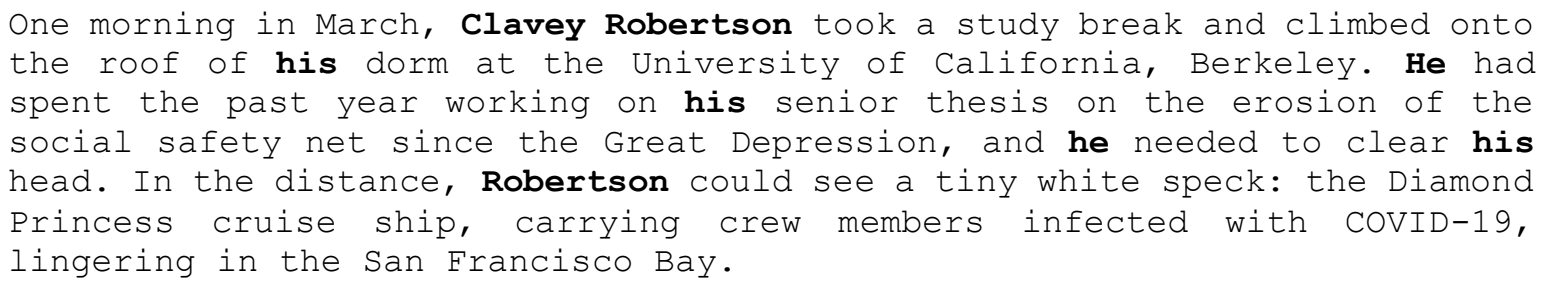

According to the excerpt 2 above, it can be seen that the words in the bold type are classified as personal references. The identity of the underlined terms in bold are retrieved by the reference to earlier mentioned items in the paragraph of table 2. Both he and his are identified as the reference of a California university, Berkeley student named Clavey Robertson. The writer of the article knows very well how to relates the sentences to tie one another. Those references are used cohesively to link one clause to other clauses and make the meaning well accepted.

\section{Excerpt 3}

Two months later, Robertson's transition to adulthood is in limbo. He skipped his online commencement and he's living in his childhood bedroom, which had been converted to a guest room. His parents have lost their travel agency work, and his own job prospects have dried up. "No longer am I just a student writing about the Great Depression," he says. "Now there's a depression."

Equally, the excerpt 3 above depicts another example of a reference found in the data of the article. It can be seen that the personal pronouns $\mathrm{He}$ illustrated in the figure above plays as an anaphoric reference where it has been mentioned in the earlier which is identified as Robertson. The article writer focuses on Robertson because he is the one who talked about in the article. So that, the writer mostly used personal pronouns mentioned in the figure such as $\mathrm{He}$, his, and I. Meanwhile, It is also found another personal pronoun namely possessive adjective pronoun indicated by their. This pronoun relates to the previous information (anaphoric) of the word "parents". It informs the readers that Robertson's parents have lost their job as travel agency. 


\section{Ellipsis}

\section{Excerpt 4}

Two months later, Robertson's transition to adulthood is in limbo. He skipped his online commencement and he's living in his childhood bedroom, which had been converted to a guest room. His parents have lost their travel agency work, and his own job prospects have dried up. "No longer am I just a student writing about the Great Depression," he says. "Now there's a depression."

According to the excerpt above, ellipsis grammatical cohesion can be found in the text provided in the table which is indicated by relative pronoun "which". The relative pronoun "which" here refers to the earlier noun "bedroom". Additionally, in the second column, it shows another example of ellipsis found in the data. In the second data, the writer of the article applies relative pronoun "who" functions to connect a clause or phrase to a noun or pronoun mentioned in the previous clause. In this case, the use of this relative pronoun is to refer to people or persons mentioned in the earlier clause that is "Sam Nelson". It can be said the both relative pronouns "which" and "who" contain critical information because each provides important information to the readers. In so doing, these relative pronouns make the clauses link to one another to create a semantic link.

\section{Substitution}

\section{Excerpt 5}

School is often a refuge from the gusts of history. But the events that rupture the classroom routine, from President Kennedy's assassination to 9/11, tend to be the ones that stick with students forever.

The above figure presents an example of substitution found in the data. It is identified by the use of "ones" which used to link to the previous clause. This word substitutes for another word which represents to whole clauses described in the figure above. However, the "ones" in the clause above refers to the word "events" which depicts President Kennedy's murder. The writer of the article tries to tell a history for the readers about a situation that happened in $9 / 11$ that stays in students' mind.

\section{Conjunction}

\section{Excerpt 6}

There's no way for there to be closure," says Sam Nelson, who recently graduated with a journalism degree from the University of Missouri. "I know in real life, closure doesn't exist, but this is one of the last moments for young people to say goodbye to young adulthood and move into the next phase of their lives.

Based on excerpt 6 above, there two types of conjunctions existed in the clauses. Those conjunctions are identified as additive and adversative conjunctions comprises and as well as but. The function of these conjunctions is used to connect between two or more sentences or clauses stated in the figure about. It can be seen that additive conjunction "and" is applied by the writer to relate the two clauses making the sentence cohesiveness. Whilst, the adversative conjunction "but" functions to show that there is a contrast clause between the 
previous or upcoming clauses. However, the use of both conjunctions "but" and "and" function to make a semantic link among clauses in the text.

\section{Lexical Cohesive Devices}

\section{Repetition}

There are some repetition words used by the writer in writing the news article. These examples are illustrated in the figure below

\section{Excerpt 7}

College graduation is often marked by an adjustment period, as students leave the comforts of campus to find their way in the raw wilderness of the job market. But this year's graduates are staggering into a world that is in some ways unrecognizable. More than 90,000 Americans have died; tens of millions are out of work; entire industries have crumbled. The virus and the economic shock waves it unleashed have hammered Americans of all ages. But graduating in the midst of the coronavirus pandemic will have enduring implications on the Class of 2020: for their memories, their earning power, and their view of what it means to have a functional society. For these young adults, the pandemic represents not just a national crisis but also a defining moment.

It can be seen in the figure above that some words are repeated such as graduation and pandemic. The writer of the article repeats these words because he tries to explain and give information to the readers about graduation in the pandemic moment. He uses the word "graduation" several times since it uses in a different part of speech, for example: both graduation and graduates are nouns therefore, both are used differently. Graduation indicates the ceremony of conferring degrees or diplomas, as at a college or school. Thus, a graduate is a person who has received a degree or diploma in completing a curse of study, as in university, college or school. Other than those, the pandemic is another word which that is repeated by the writer. These words are repeated because the writer emphases on a situation that occurred in the country recently. He explains that the situation of the students' graduation will remain for good since it gives a huge impact on everyone in the world. As a result, these repletion connects one clause to another clause cohesively.

\section{Synonym}

\section{Excerpt 8}

By Friday, March 13, an eerie silence fell on campuses across the nation. "Something about that day was really weird, because every time my friends and I would say 'See you later' or 'Catch you after break,' I just had this sinking feeling that I wasn't going to see them," says Vincent Valeriano, a member of Iowa State University's Class of 2020. "Saying goodbye felt like it carried a lot more weight than it used to." He ended up watching his online -graduation -ceremony at home, in his pajamas.

The overall number of postings on the online jobs platform ZipRecruiter have fallen by nearly half since mid-February, while new postings for entry-level positions have plummeted more than 75\%, according to ZipRecruiter labor economist Julia Pollak.

Based on the data provided, it can be seen that there are some synonym found in the data. It can be illustrated in the word "eerie" which has a similar meaning to the word "weird". These two words 
have the same meaning that it is connected with fear or destiny. So it the data above, the writer of the article wants to show to the readers that many campuses in the United of State America have closed their campuses due to corona viruses which spread all over the country. This situation makes many students feel that they will not meet each other shortly because of this corona virus happened in the country. The other synonym found in the data is indicated by the expression of farewell such as see you later, catch you after break and saying good bye. These are all identified as synonyms. These phrases mean farewell and are used when we want to end our conversation. The next synonyms found in the data are the word fallen and plummeted. These two words are have similar meaning that it means there is decreasing rapidly in value or amount of something. It can be seen in the data above that the writer of the article emphasizes to a situation that there are a significant decreasing of online jobs platform as well as entry-level positions since mid-February.

It can be said that the writer of the article employs those synonymous words or phrases to make a semantic link among sentences he made. As a result, the sentences in the data above are interrelated and make cohesiveness of the text.

Below is another example of synonyms made by the writer of the article. The illustration of these synonyms can be seen in the figure 9 below.

\section{Excerpt 9}

Sanchez, who worked two jobs and started her own eyelash-extension business to help pay for school, has applied for more than 70 jobs in recent weeks without success. Williams, who dreams of working in the entertainment industry, had no luck with at least 15 jobs and struck out with fellowships that are no longer taking applicants; now she's cobbling together gig work. Robertson had planned to try to get a job in labor activism; these days, he's considering graduate school instead.

According to the example provided above, there are two synonym phrases found in the data. The first one is the phrase "without success" which has the same meaning as "no luck". It indicates that the writer wants to show the readers of the article that Sanchez has applied many positions in some companies unsuccessfully. He was rejected in more than 70 jobs. Additionally, William undergoes a similar experience with Sanchez that he has no luck in applying some jobs. He has rejected in at least 15 jobs. The COVID-19 has caused many problems in most countries especially in job vacancies. This situation made Sanchez and William were rejected in some positions and make them to struggle in this situation. Another example of synonyms found in the data. The phrase cobbling together gig work is a synonym with try to get a job. These phrases informs the readers that Sanchez and Robertson are struggling to find jobs. They cannot get jobs due to the Corona Virus situation occurred in their country. For now, Robertson will focus on his study. The use of these synonyms is to make link among sentences. The writer of the article is aware of how to connect his sentences into semantic ties. The use of cohesive devices, especially lexical cohesion of synonym, is to make his writing more accurate and natural.

\section{Antonym}

\section{Excerpt 10}

The Class of 2020 hugged their closest friends and mourned their lost semester, but scattered back home without so much as a goodbye to many people they'd lived with for years. Acquaintances who laughed in hallways or shared inside jokes in seminars simply disappeared. Fraternities and sororities canceled their formals and philanthropy events, attempting Zoom 
happy hours that didn't come close to the real thing. For some couples, casual hookups quickly escalated into long-distance relationships. Others quietly packed up their feelings for college crushes and left without saying a word.

Based on the figure 10 above, there are two antonyms found in the data. These pairs of words are mourned and happy as well as laughed and jokes. It can be seen that mourned in the data above shows that students of the class 2020 are sad with their lost semester due to COVID 19. In contrast, it is stated that they feel happy because they do not need to meet each other since they can meet through zoom. Furthermore, the word laughed here informs the readers that some students laugh because of something they talked about while they walk in the hallways. In contrast, the students make some jokes when they join seminars or other events mentioned in the figure above. The writer of the article presents his writing in smooth and well-organized writing because he can put a semantic link in his writing through the use of some antonyms.

\section{Hyponym}

\section{Excerpt 11}

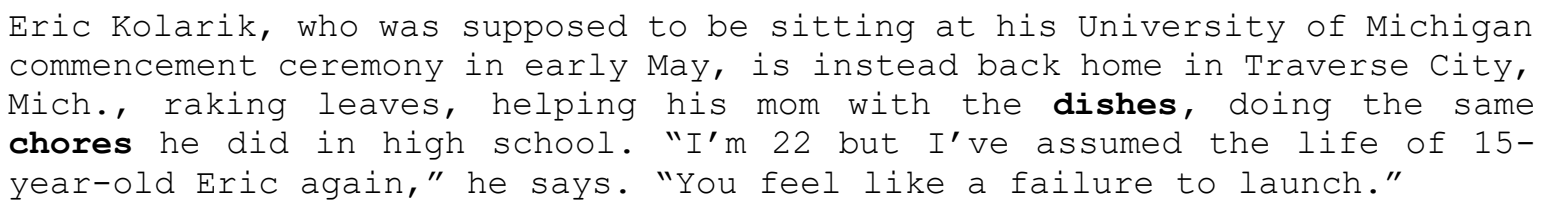

The above figure 11 is the example of another lexical cohesion namely hyponym found the article. It is indicated by the words dishes and chores. These two words are used to make the sentences cohesively ties. It can be said that dishes are part of chores. The writer of the article explains that Eric Kolarik helps his mother to do some house chores and one of them is doing the dishes. As a result, the sentences in the paragraph above are interrelated and they makes semantic links among clauses and make it coherent.

\section{CONCLUSION}

It can be summed up that the use of cohesion can create a semantic link within the text between sentences and paragraphs. Besides, it also can make the sentences or paragraphs be cohesive Moreover, in terms of cohesive devices, the writer of the article employs some simple cohesive devices such as reference, ellipsis, conjunction and substitution. Based on the findings, the most occurrences of the grammatical cohesive devices are references. Meanwhile, he also uses some lexical cohesive devices in his text namely repetition, synonym, antonym, and hyponym. These types of cohesive devices are the central devices for making texts hang together experientially and their function is to create the texture of the text. It also becomes an important aspect of creating grammatical meaning within the text.

\section{BIBLIOGRAPHY}

Bloor T. \& Bloor M. (1995). The functional analysis of English: a Hallidayan approach. London: Arnold. 
Butt, D et al. (2000). Using Functional grammar: An explorer's Guide Second Edition. Sydney "National Centre for English Language Teaching and Research Maguire University.

Eggins, S. (1994). An introduction to systemic functional linguistics. New York: Pinter Publishers.

Eggins, S. (2004). An introduction to systemic functional linguistics $\left(2^{\text {nd }}\right.$ ed.). London: Continuum International Publishing Group

Fontaine, L. 2013. Analyzing English Grammar: a Systemic Functional Introduction. New York: Cambridge University Press.

Gerot, L., \& Wignell, P. (1994). Making sense of functional grammar. Cammeray, NSW: Antipodean Educational Enterprises

Halliday, M. A. K. (1985). Introduction to Functional Grammar. London: Edward Arnold.

Halliday, M. A. K. (1994). An introduction to functional grammar. Hodder, London.

Halliday, M.A.K. and C.M.I.M. Matthiessen. 1999. Construing Experience Through Meaning: A Language-based Approach to Cognition. London: Continuum.

Halliday, M. A. K. \& Matthiessen, C. (2004). An Introduction to functional grammar. Third edition. London: Edward Arnold.

Halliday, M. A. K. \& Hasan, R. (1976). Cohesion in English. London: Longman.

Martin, J. R. (1984). Language, register and genre. In F. Christie (Ed.), Children Writing, (pp. 21-29). Geelong: Deakin University Press. 173

Martin, J. R. (1997). ‘Analyzing genre: Functional parameters'. In F. Christie \& J. R. Martin (Eds.), Genre and institutions: Social processes in the workplace and school, (pp.339). London and New York: Continuum.

Martin, J. R. (1998). 'Linguistics and the Consumer: The Practice of Theory'. Linguistics and Education, 9(4): 411-448.

Martin, J. R. (1992). English Text: System and structure. Amsterdam: John Benjamins Publishing Company.

Martin, J. R. \& Rose, D. (2003). Working with Discourse: Meaning Beyond the Clause. London: Continuum.

Matthiessen, C.M.I.M. 1995. Lexicogrammatical Cartography: English System. Tokyo: International Language Science Series.

Nwogu, K. \& Bloor, T. (1991). Thematic progression in professional and popular medical texts. E. Ventola (Ed.), Functional and systemic linguistics: approaches and uses, (pp. 369-384). Berlin: Mouton de Gruyter. 
Paltridge, B. (2000). Making Sense of Discourse analysis. Gold Coast, Queensland: Antipodean Educational Enterprises.

Paltridge, B. (2006). Discourse analysis. London: Continuum.

Thompson, G. 1996. Introducing Functional Grammar. London: JW Arrowsmith Ltd.

Wang, L. (2007). Theme and rheme in the thematic organization of text: Implication for teaching academic writing. Asian EFL Journal, 9(1), 1-11.

Witte, P. S., \& Faigley, L. (2008). Coherence, cohesion, and writing quality. Collage Composition and Communication, 32(4),189- 204. 